\title{
GOMMENTS
}

\section{NEPA'S ROLE IN PROTEGTING THE WORLD ENVIRONMENT}

\section{INTRODUCTION}

The National Environmental Policy Act (NEPA) of 1969, 1 is designed to ensure that actions of the United States government reflect environmental concerns as well as political and economic pressures. It requires all federal agencies undertaking "major actions" that may have significant environmental effects to prepare an environmental impact statement (EIS) detailing foreseeable environmental consequences of and alternatives to the proposed action. ${ }^{2}$ Whether NEPA requires an EIS for federal projects undertaken abroad has been a continuing source of controversy. The federal agencies often object to preparing EIS's because of the extra time, expense and effort they involve. ${ }^{3}$ The foreign country may object (often supported by our State Department ${ }^{4}$ ) on the ground that its sovereignty will be infringed by such preparation. ${ }^{5}$ Both groups claim that Congress did not intend NEPA to apply to foreign projects.

Congress never fully considered the issue, so the statutory language and legislative history of the Act are inconclusive. ${ }^{6}$ The federal courts have largely avoided the issue, ruling explicitly on NEPA's foreign reach in only one case. ${ }^{7}$ Agency practices have varied considerably, ${ }^{8}$ and the Executive Order which was promulgated to resolve the

42 U.S.C. $\S \S 4321-4361$ (1976).

2 Id. $\S 4332(2)(\mathrm{C})$.

s See infra note 47 .

- See infra notes 74-75 and accompanying text.

- See infra notes 97-154 and accompanying text.

- See infra notes 48-72 and accompanying text.

7 Natural Resources Defense Council, Inc. v. Nuclear Regulatory Comm'n, 647 F.2d 1345 (D.C. Gir. 1981) (no EIS required for a nuclear reactor export license when the effects are confined solely to the recipient country). Other courts have avoided the issue by assuming NEPA applicable or because defendants either failed to object to NEPA's extraterritorial reach or settled. See Sierra Club v. Adams, 578 F.2d 389 (D.C. Cir. 1978) (in an action contesting construction of highway in Panama, the court assumed, without deciding, that NEPA was fully applicable to construction in Panama); National Org. for the Reform of Marijuana Laws v. United States, 452 F. Supp. 1226 (D.D.C. 1978) (NEPA assumed fully applicable to paraquat-spraying program in Mexico); Sierra Club v. Atomic Energy Comm'n, 4 ENVTL. L. REP. (ENVTL. L. INST.) 20,685 (D.D.C. 1974) (AEC agreed to prepare a generic EIS on the nuclear export program, allowing the court to avoid the issue); People of Enewetak v. Laird, 353 F. Supp. 811 (D. Hawaii 1973) (NEPA found applicable to United States trust territories; unnecessary for court to decide NEPA's general extraterritorial reach).

8 See, e.g., Export-Import Bank Regulations, 12 C.F.R. $\S \S ~ 408-409$ (1983); Agency for International Development Regulations, 22 C.F.R. $\S 216$ (1982); Department of Defense Regulations, 32 C.F.R. § 197 (1982). 
controversy falls short of fulfilling NEPA's mandate. ${ }^{9}$ Fourteen years after the enactment of NEPA it is still unclear when the EIS process should be applied to United States actions abroad. ${ }^{10}$

This Comment argues that courts should extend their active role in NEPA litigation concerning domestic projects to foreign agency activity and provide needed guidance in interpreting the statute. The Comment first looks at EIS's generally and suggests their potential usefulness for agency decisionmaking concerning actions abroad. After examining some areas of federal foreign-policy-making in which EIS's would make a significant contribution, and suggesting that environmental concerns cannot effectively be addressed on a national basis, the Comment reviews NEPA's statutory language and legislative history, and an Executive Order which tried to resolve the conflicting interpretations.

The Comment concludes that the primary objection to NEPA's application abroad, the potential infringement on foreign sovereignty, is not valid in many cases. Furthermore, when it is, the language of NEPA is flexible enough to take that objection into account. Thus, NEPA applies to foreign projects undertaken by federal agencies, and courts, as a general rule, should require that the EIS requirement apply but should permit exceptions on a case-by-case basis under a balancing test the Comment suggests. That test will allow courts to review agency decisions on whether to prepare an EIS for federal actions abroad in a manner which fulfills Congress's environmental mandate but does not infringe unnecessarily on foreign sovereignty.

\section{EnVIronmental Impact Statements and Their USEFUlNeSS fOR FEDERAL ACTIONS ABROAD}

\section{A. General Considerations}

The National Environmental Policy Act of 1969 (NEPA) $^{11}$ expresses a mandate so pervasive that it has been called an "environmental bill of rights." "12 In order to ensure that the government adopts a systematic, interdisciplinary approach to project design, section

- See infra text accompanying notes 76-96.

10 For example, eight years after NEPA's enactment, Congress had the opportunity to consider its foreign reach during debate on the Nuclear Nonproliferation Act. Congress declined to settle the question, even in the limited context of nuclear exports. See 124 CONG. REC. 2523 (1978) (remarks of Senator McClure).

1142 U.S.C. \$\$ 4321-4361 (1976).

12 F. Grad, 2 Treatise on ENVIRonmental Law 9-6 (1980) (quoting Hanks \& Hanks, An Environmental Bill of Rights: The Citizen Suit and the National Environmental Policy Act of 1969, 24 RUTGERS L. REV. 230, 269 (1970)). 
$102(2)(\mathrm{G}),{ }^{13}$ the major action-forcing provision, requires federal agencies to prepare an EIS for all major actions with significant environmental effects. The provision raises threshold questions of whether an action is "major," whether it is sufficiently "Federal," and whether the impact on the environment is "significant" enough to require an EIS. ${ }^{14}$

The tests for "major" action and "significant" effects tend to merge, with agencies preparing an initial environmental assessment to see if there will be a significant impact, in which case they will prepare a formal impact statement. ${ }^{16}$ The Council on Environmental Quality (GEQ), an advisory body created by NEPA, has provided a list of relevant considerations in determining whether to prepare an EIS. ${ }^{16}$ Some of these are: the degree to which an action affects public health and safety, the environmental riskiness of the project, effects on endangered species, and the probability that the action may establish a precedent for future actions.

Section $102(2)(C)$ requires that an EIS address five areas, ${ }^{17}$ including any unavoidable adverse impact on the environment and resources, and any reasonable alternatives to the proposal. The information gathered in the EIS must be supplemented by consultations with other agencies, ${ }^{18}$ and comments made by the public. ${ }^{18}$

1342 U.S.C. $\S 4332(2)(C)$ ("all agencies of the Federal Government shall . . . (C) include in every recommendation or report on . . . major Federal actions significantly affecting the quality of the human environment, [an EIS]").

14 These concepts have been defined in the NEPA regulations. 40 C.F.R. $\S 1508$ (1982). In addition, the courts have adopted a case-by-case approach to determine what actions are within a particular definition. See, e.g., Defenders of Wildlife v. Andrus, 627 F.2d 1238 (D.C. Cir. 1980) (granting licenses may be federal action); State of Alaska v. Andrus, 391 F.2d 537 (9th Cir. 1979) (substantial federal funding may constitute federal action); Sierra Club v. Morton, 514 F.2d 856 (D.C. Cir. 1975) (permission or approval by federal agency of private action, such as approving leases, is federal action). See generally F. ANDERSON, NEPA IN THE COURTS 61-96 (1973). The courts have also defined impact on the "human environment" to require an impact on the physical environment. If that is present, however, an environmental impact statement can look at effects on the social, economic, and cultural environment. See, e.g., Breckinridge v. Rumsfeld, 537 F.2d 864, 866 (6th Cir. 1976) and cases cited therein.

is U.S. COUNCIL ON ENVIRONMENTAL QUALITY, ENVIRONMENTAL IMPACT STATEMENTS: AN ANALYSIS OF SIX YEARS' EXPERIENCE BY SEVENTY FEDERAL AGENCIES 16 (1976) [hereinafter cited as EIS REPORT].

16 CEQ Guidelines, 40 C.F.R. \& 1508 (1982).

17 (i) the environmental impact of the proposed action,

(ii) any adverse environmental effects which cannot be avoided should the proposal be implemented,

(iii) alternatives to the proposed action,

(iv) the relationship between local short-term uses of man's environment and the maintenance and enhancement of long-term productivity, and

(v) any irreversible and irretrievable commitments of resources which would be involved in the proposed action should it be implemented.

42 U.S.C. $\S 4332(2)$ (C) (1976).

18. Id.

10 CEQ Guidelines, 40 C.F.R. $\S 1503.1(a)(3)-(4)$ (1982). 
NEPA's exceedingly general language invites judicial interpretation, so, although NEPA does not specifically provide for judicial review, ${ }^{20}$ the EIS requirement has been used by plaintiffs to gain review. In fact, NEPA's "effectiveness is owed in large part to the fact that [the EIS requirement] provides a point of entry for concerned citizens to challenge government actions and to invoke the spirit of other sections of NEPA."21

Preparation of an EIS is a procedural requirement designed to ensure fully informed decisionmaking. Even if a significant negative environmental impact is revealed, the agency remains free to proceed with its action. ${ }^{22}$ However, in reaching its decision, the agency must give environmental factors good faith consideration, ${ }^{23}$ and a reviewing court may overturn the decision to proceed with the action if it is found to be arbitrary and capricious. ${ }^{24}$ Thus, an environmentally concerned group has access to the courts to allege that an agency failed to prepare an EIS when the statute required one ${ }^{28}$ or that the EIS prepared by an agency was inadequate. ${ }^{26}$ NEPA provides new ground for review of administrative actions, but it does not create any new causes of action. ${ }^{27}$

\section{B. The EIS in the International Arena}

In the international sphere, the benefits of EIS review have great potential to improve federal programs, to help the United States avoid diplomatically embarrassing program failures, to inform other nations of the impact of American foreign actions, and to protect the United States from environmental harm.

One important example is provided by environmental analysis of foreign aid programs. ${ }^{28}$ In addition to preventing pollution and protecting the existence of endangered species in other countries, environmental analysis can improve the efficiency and probability of success of many assistance programs. In many instances, failure to anticipate environmental consequences has caused programs to fail or to have un-

20 See F. ANDERSON, supra note 14, at 16-17.

21 Id. at $\mathrm{v}$.

23 See infra text accompanying note 122 .

23 See F. GRAD, supra note 12 , at $9-122$ to $9-124$.

14 See id.

2. Maryland-National Capital Park and Planning Comm'n v. United States Postal Serv., 487 F.2d 1029 (D.C. Cir. 1973).

so Sierra Club v. Adams, 578 F.2d 389 (D.C. Cir. 1978) (challenge to adequacy of EIS prepared for Panama highway proposal).

17 F. GRAD, supra note 12 , at $9-119$ to $9-120$.

2s Most foreign aid is administered by the Agency for International Development, an independent body within the Department of State. Its statutory authorization is found in the Foreign Assistance Act of 1961, 22 U.S.C. $\$ \S 2151-2443$ (1976). 
foreseen, harmful results. ${ }^{29}$ For example, poorly planned agricultural irrigation projects, designed to increase arable land, may raise a salty water table to the point where a high level of salinity in the topsoil removes the land from agricultural use. ${ }^{30}$ An attempt to increase arable land through tropical deforestation ${ }^{31}$ may cause floods and droughts, devastating the local population and increasing demands on United States and international disaster-relief. ${ }^{32}$ These undesirable consequences may be avoided by proper environmental planning, and an EIS prepared in full compliance with NEPA might suggest alternative means of providing the same aid, avoiding undesirable consequences. ${ }^{\text {ss }}$ An EIS also provides public information about the possible consequences of agency actions and the available alternatives. Such information could be very useful to the other nation involved, which may not have the resources and information required to assess the impact of a United States action. This informational role of an EIS helps to equalize the information available to both nations, provides for informed decisionmaking in both, and obviates many of the concerns about sovereignty which may seem to limit the scope of the EIS requirement.

Finally, the EIS requirement for federal actions abroad protects vital American interests. There is great potential for harm to the repu-. tation of the United States as a supplier of goods and services to other nations if federal actions are undertaken with callous disregard for environmental concerns. That potential is present even though most of the agency projects constitute much-needed aid to poor countries.

It is useful to imagine the diplomatic and political animosity that may be engendered as a result of major project failures. The Soviet failure at the Aswan High Dam in Egypt presents a lesson which

30 For a detailed and enlightened discussion of this problem see Comment, Controlling the Environmental Hazards of International Development, 5 ECOLOGY L.Q. 321, 322-27 (1976).

so Id. at 326.

si Id. at 330 .

22 CEQ \& U.S. DEP'T OF STATE, GLOBAL FUTURE: TTME TO ACT, REPORT TO THE PRESIDENT ON GLOBAL RESOURCES, ENVIRONMENT AND POPULATION 29-31 (1981) [hereinafter cited as GLOBAL FUTURE].

ss There are many opportunities to shape development in ways that protect renewable resources for long-term productivity-opportunities that are open to both rich and poor countries. For example, dams or new industries can be better planned to avoid adverse impacts on croplands or fisheries. Transportation systems may be developed that, unlike the auto highway system, do not encourage sprawl and are not solely dependent on petroleum. Agricultural systems can be built on a more sustainable resource-conserving basis, which makes use of organic as well as chemical fertilizer, interplanting of legumes or development of new nitrogen-fixing crops, use of farm machinery that is the right size to fit the job, and pest control methods that use natural predators and selective pesticides rather than broad scale application of persistent, destructive chemicals. 
should not be ignored. The project was a major blow to Soviet credibility in aiding underdeveloped countries. ${ }^{34}$

The United States interest in avoiding direct environmental damage from projects it undertakes abroad is thus clear. In addition to direct environmental effects in the other country, there remain two additional levels of environmental concern. These have been called the "boomerang" effects, in recognition of the integrated nature of the environment whereby an action taken abroad "boomerangs" back to the United States. ${ }^{35}$ The "primary boomerang" effect is illustrated by the Agency for International Development (AID)'s pesticide export program, which raises the possibility of the return of toxic pesticides via trade winds or through the food chain..$^{36}$ Another example might be the export of a nuclear reactor, such as was recently completed to the Philippines. The proposed site was within 40 miles of American naval and air bases, ${ }^{37}$ in a volcano and earthquake zone. ${ }^{38}$ In addition to the obvious potential for harm to American servicemen and their families, a nuclear accident could cause significant damage to the world environment. ${ }^{38}$ The United States has an interest in preventing such "primary boomerang" effects.

United States interests are also implicated in what might be called "secondary boomerang" effects. Some recent studies have concluded that if present trends and policies continue, there will be progressive exhaustion of world resources and degradation of the global environment. ${ }^{40}$

Unless nations of the world take prompt, decisive action to alter the trends, . . . the next 20 years may see a decline in the earth's capacity to support life, while rapid population growth continues; a steady loss of croplands, fisheries, forests, and plant and animal species; and degradation of the earth's water and atmosphere. ${ }^{41}$

st According to CEQ Chairman Charles Warren, the Aswan Dam project dramatically increased the incidence of a blood disease caused by a water-borne parasite. He cites this as "the best known case of development gone wrong." C. Warren, Remarks, reprinted in Yost, American Governmental Responsibility for the Environmental Effects of Actions Abroad, 43 ALB. L. REV. 528, 533 (1979).

${ }^{35}$ Comment, supra note 29 , at 350 .

so Id. at 353.

${ }^{37}$ Natural Resources Defense Council, Inc. v. Nuclear Regulatory Comm'n, 647 F.2d 1345, 1351 (D.C. Cir. 1981). Thirty-two thousand Americans were stationed at Clark Air Base, 40 miles from the site.

so Id. at 1370 n.14.

30 The fact that the Philippines does not have any stable salt formations for disposal of radioactive wastes is also of concern. See Yost, supra note 34, at 533.

10 GLOBAL FUTURE, supra note 32, at $i$.

61 Id. The United States interest in this problem is not limited to moral concerns. Prevention 
The potential role of an EIS in protecting environmental quality and preventing global resource conflicts is perhaps best illustrated in the area of energy, where the interdependence of nations is especially plain. The world's supply of fossil fuels is scarce, and the United States interest in easing demand for such fuels is clear. So, for example, if a developing country calls on the United States to design a power system for a village, an EIS can help the foreign government by pointing out alternatives which incorporate renewable energy sources and conservation. The EIS helps the United States direct its assistance in a manner designed to reduce global energy demands, thereby reducing the possibility of global energy conflicts.

Overuse of fossil fuels also contributes to degradation of the human environment. First, fossil fuels increase the level of carbon dioxide in the atmosphere which may eventually alter the world's climate sufficiently to disrupt human activities, especially agriculture. ${ }^{42}$ Second, release of sulfur and nitrogen oxides into the atmosphere may cause acid rain which threatens fish life, decreases agricultural and forest yields, and contaminates drinking water. ${ }^{43}$ An EIS analysis would evaluate these costs and might suggest less damaging alternatives.

The problems currently facing the world environment which affect the United States are not limited to energy. Global overpopulation, agricultural impoverishment, and destruction of marine and freshwater resources are all matters which affect the United States. ${ }^{44}$ For example, increasing numbers of "ecological refugees" have resulted from the inability of Third World countries to foster economic development while maintaining environmental quality. "In many parts of the world, from worn out cropland, barren rangeland, and degraded forestland, migration is rapidly accelerating. . . . Political barriers may be erected to contain the migration, but they are hard to enforce."45

None of these problems are solved by having federal agencies pre-

of global environmental degradation is also a matter of basic national security.

A downward spiral of poverty, and resource degradation and a growing disparity between rich and poor could increase the possibilities for frustration and resentment from those on the short end of the wealth equation, making them more susceptible to exploitation by others and incitement to violence. Such developments can contribute to political instability that can threaten the security of all nations, including our own.

Id. at 5 .

42 Id. at 2.

is Rosencranz, International Perspectives on the Long-Range Transport of Sulfur Oxides, in Air POLlUtion CONTROL: NATIONAL AND INTERNATIONAL PERSPECTIVES 82, 83 (ABA Standing Comm. on Envtl. Law, 1979); see also Pearce, The Acid Rain Threat, WORLD PRESS REV., Oct. 1982 , at 26.

4See generally Global. FUTURE, supra note 32.

4 Id. at 7. 
pare EIS's. A coordinated federal policy to assess global needs and promote international cooperation is necessary. ${ }^{46}$ Requiring EIS's for federal actions abroad is, however, a useful first step in the direction of global environmental responsibility. At the least, the EIS points out the potential environmental injury which could result from such actions and informs the other nation involved, allowing it to make the choice that best suits its national interests. EIS's could also be used by the federal government to insure that our aid or cooperation best promotes our interests in an interdependent world.

Many so-called "foreign" actions have an impact upon the environment and thus an effect upon the health and welfare of American citizens. Preparation of an environmental impact statement would substantially enhance informed decisionmaking and further the goal of environmental protection. The substantial benefits that would accrue from the preparation of EIS's for federal actions abroad seem clear. ${ }^{47}$ The question is whether Congress intended the EIS requirement to apply to those federal actions.

\section{The Battle over Congressional INTent}

\section{A. Legislative Intent}

The language and legislative history of NEPA are ambiguous on the issue whether an EIS must be prepared for federal actions abroad. ${ }^{48}$ Parts of the Act resemble constitutional provisions in their

46. Id. at 214-29.

47 It is difficult to weigh those benefits against the costs of EIS preparation (in terms of time and money) because the NEPA component of decisionmaking is not readily separable from other considerations. The indications in the domestic field are quite positive, however. For example, the Department of Transportation (DOT) has modified or dropped scores of major highway or airport projects "as a result of the EIS process and DOT's resulting capacity and determination to avoid adverse effects." EIS REPORT, supra note 15, at D-2. The Corps of Engineers spent about $\$ 21$ million in 1974 on EIS's, approximately 1.2 percent of its annual operating budget. In 1975, the Nuclear Regulatory Commission spent about $\$ 15$ million on NEPA, "which is about 2.2 percent of the cost of one nuclear power plant." Id. at 43-45. Similarly, the Environmental Protection Agency has found EIS's to be a positive influence in their waste water treatment program:

After calculating project cost increases resulting from an EIS and project cost savings resulting from an EIS, EPA found that even though costs increased in a majoriy (31) of the plants, the savings in the 19 other plants, where costs were reduced, more than offset total increases. The net savings as a result of EIS's for 49 plants was $\$ 34.5$ million. One EIS achieved extraordinary savings of $\$ 438.4$ million because a plant was redesigned on a much smaller, more appropriate scale than the one originally proposed.

11 CEQ ANN. REP. 372 (1980).

4o The commentary has come down solidly on both sides of the fence. Compare Note, Extraterritorial Scope of NEPA's Environmental Impact Statement Requirement, 74 MICH. L. REV. 349 (1975) (favoring extraterritorial application) with Brower, Is NEPA Exportable?, 43 ALB. $L$. Rev. 513 (1979) and Note, The Scope of the National Environmental Policy Act: Should the 102(2)(C) Impact Statement Provision Be Applicable to a Federal Agency's Activities Having 
breadth and vagueness. Commentators who have focused upon the statutory language have not agreed on whether NEPA does or does not apply to federal actions abroad. ${ }^{49}$ Other commentators argue that an EIS requirement would constitute an extraterritorial application of United States law. ${ }^{\mathbf{5 0}}$ They invoke a general presumption against extraterritorial applications of United States law "unless the contrary is clearly indicated by the statute." "\$1 Thus, it is claimed, such an EIS requirement would only arise if Congress explicitly stated in the statute that an EIS shall be prepared for federal actions undertaken abroad.

Such analysis is not entirely convincing. Despite a good deal of vague language in the statute, the section requiring EIS preparation is fairly straightforward. Section 102(2)(C) "directs that, to the fullest extent possible, . . . all agencies of the Federal Government shall . . . include in every recommendation or report on proposals for legislation and other major Federal actions significantly affecting the quality of

Environmental Consequences Within Another Sovereign's Jurisdiction?, 5 SYRACUSE J. INT'L L. \& COMM. 317, 318 (1978) [hereinafter cited as Environmental Consequences] (opposing extraterritorial application).

10 At the root of the statutory debate is congressional language vacillating between a "national policy" to benefit "all Americans" and the desire to protect the quality of "the human" or "man's" environment or "biosphere." The linguistic schizophrenia is amply demonstrated by the congressional declaration of national environmental policy in $\S 101$ :

(a) The Congress, recognizing the profound impact of man's activity on the interrelations of all components of the natural environment, . . . declares that it is the continuing policy of the Federal government, . . . to create and maintain conditions under which man and nature can exist in productive harmony, and fulfill the social, economic and other requirements of present and future generations of Americans.

42 U.S.C. \$ 4331(a) (emphasis added). In particular, the requirement of an environmental impact statement applies to "major Federal actions significantly affecting the quality of the human environment," and calls for an assessment of "the relationship between local short-term uses of man's environment and the maintenance and enhancement of long-term productivity." Thus, environmental impact statements are called for when federal action significantly affects man's human environment, which would appear to be a global requirement, but this is qualified by a congressional purpose to "assure for all Americans" a healthful environment. The message is unclear and commentators have reached divergent results. CEQ used the language on the human environment to conclude that:

[t] the "human environment" is not limited to the United States, but includes other countries and areas outside the jurisdiction of any country (e.g., the high seas, the atmosphere). The Act contains no express or implied geographic limitation of environment impacts to the United States or to any other area. Indeed, such a limitation would be inconsistent with the plain language of NEPA, its legislative purpose, the Council's Guidelines, and judicial precedents.

U.S. Council on Environmental Quality, Memorandum on the Application of the EIS Requirement to Environmental Impacts Abroad of Major Federal Actions (Sept. 24, 1976), reprinted in 42 Fed. Reg. 61,068 (1977) [hereinafter cited as GEQ Memo]. See also Krauland, NEPA, Nukes and Non-Proliferation: Clarifying the Transnational Impact Statement Mandate in Nuclear Export Licensing, 4 HASTINGS INT'L \& COMP. L. REV. 201, 214-25 (1981) (analyzing the statutory language and concluding that the EIS requirement does not apply in the context of nuclear export licensing).

Bo See, e.g., Environmental Consequences, supra note 48; Brower, supra note 48.

s1 RESTATEMENT (SECOND) FOREIGN RELATIONS LAW OF THE UNITED STATES § 38 (1965) [hereinafter cited as RESTATEMENT]. 
the human environment, a detailed statement" ${ }^{\text {} 52}$ of the environmental impact of that proposed action. This language is unambiguous: the requirement applies to "all agencies," and Congress made no specific exemption for the Department of State or agencies involved in foreign affairs. $^{\text {s3 }}$

The argument that an EIS cannot be required because of the general presumption against extraterritorial applications of law prejudges the question. It can be convincingly argued that an EIS requirement is not an extraterritorial application of law. ${ }^{\text {st }}$ Even if requiring an EIS were an extraterritorial application of law, the negative presumption is not absolute. First, as the reporters' notes to the Restatement of Foreign Relations Law indicate, "[s]ome federal statutes not specifically reaching conduct outside the territory of the United States have been applied to such conduct when it has effects within the territory of the United States." Us Under this interpretation, two generally worded statutes, the Sherman Anti-Trust Act ${ }^{58}$ and the Lanham Act $^{57}$ have been applied extraterritorially if there are economic consequences within the United States. ${ }^{58}$ NEPA's broad language could undoubtedly cover major federal activity which, if taken abroad, may have substantial environmental effects at home. ${ }^{59}$

Second, the Restatement relies on Foley Brothers v. Filardo, ${ }^{60}$ a decision "based upon the assumption that Congress is primarily concerned with domestic conditions." ${ }^{\text {It }}$ it is clear that Congress was not

s2 42 U.S.C. § 4332 (1976) (emphasis added).

ss It is unlikely that the missing exemption was a matter of gross congressional oversight. There was some agency-specific consideration. For example, Senator Muskie expressed concern that certain NEPA requirements would interfere with the operation of the Federal Water Pollution Control Administration and the National Air Pollution Control Administration. 115 CoNG. REC. 40,423 (1969). In addition, Congress did not simply overlook the issue of international environmental concerns. It paid specific attention to foreign policy by imposing an additional international cooperation requirement on all agencies in $\S 102(2)(\mathrm{F})$. Thus, it is clear that Congress considered the idea of agency-specific exemptions and that it recognized certain foreign-policy concerns when it enacted NEPA. In spite of these factors, there is no exemption for agencies acting abroad.

54 See infra text accompanying notes 116-34.

st RESTATEMENT, supra note $51, \S 38$, reporters' note (1)(ii).

so 15 U.S.C. §§ 1-7 (1976).

s7 Trade Mark Act of 1946, 15 U.S.C. $\S 1051$ (1976). The judicial interpretations of the Lanham Trade Mark Act add the requirement that the defendant be a United States national. See, e.g., Steele v. Bulova Watch Co., 344 U.S. 280 (1952).

ss United States v. Aluminum Co. of Am., 148 F.2d 416 (2d Cir. 1945) (applying U.S. antitrust laws extraterritorially); see also Steele v. Bulova Watch Co., 344 U.S. 280 (1952).

38 In a specific case, the absence of such impact may militate against preparation of an EIS, see infra text accompanying notes 192-94, but this should not work against extraterritorial application of NEPA generally. Furthermore, an aggregation of such specific, environmentally insignificant cases may have significant, deleterious Gestalt effects.

o0 336 U.S. 281 (1949).

e1 Id. at 285. 
primarily concerned with domestic conditions when it enacted NEPA. Congress employed broad, globally oriented language in both the policy and action-forcing sections. ${ }^{62}$ While such language does not prove that NEPA should apply extraterritorially, such expressions do weigh against a canon of construction which presumes a purely domestic application. ${ }^{63}$

The legislative history is not much more revealing than the statutory language as to an EIS requirement abroad. The action-forcing provisions of section 102 underwent last-minute changes leaving no time for full consideration of their ramifications. ${ }^{64}$ The few legislative scraps consist mainly of broad policy statements that do not directly address an EIS requirement for federal action abroad. This has allowed commentators to use the same legislative materials to reach opposite conclusions. ${ }^{65}$ Indeed, "it is puzzling to see authors focusing on isolated statements regarding the international environment drawing different conclusions as to NEPA's transnational application."66 While Congress may have been concerned with the global environment, it does not appear that it considered the issue explicitly.

The issue was explicitly raised at NEPA oversight hearings a year after enactment. The Department of State, employing the presumption against extraterritoriality in the absence of clearly expressed intent, maintained that NEPA did not apply to federal actions abroad. The oversight committee saw things differently:

Stated most charitably, the Committee disagrees with this interpretation of NEPA. The history of the Act makes it quite clear that the global effects of environmental decisions are inevitably a part of the decisionmaking process and must be considered in that context. ${ }^{67}$

Subsequent oversight hearings are technically not considered part of the legislative history ${ }^{68}$ However, in practice, courts will give subsequent legislative history "appropriate weight" if it aids interpretation of an

-2 See supra note 49.

es This conclusion is supported by the NEPA oversight hearings. See infra note 67 and accompanying text.

64 F. ANDERSON, supra note 14, at 9.

See supra note 48 .

6o Krauland, supra note 49, at 217. See also Comment, Federal Agency Responsibility to Assess Extraterritorial Environmental Impacts, 14 TEX. INT'L L.J. 425, 431-32 (1979). deleted).

o7 NEPA Oversight Hearings, H.R. REP. No. 316, 92d Cong., 1st Sess. 33 (1971) (emphasis

68 Regional Rail Reorganization Act Cases, 419 U.S. 102, 132 (1974) ("[P]ost-passage remarks of legislators, however explicit, cannot serve to change the legislative intent of Congress expressed before the Act's passage"). 
ambiguous statute. ${ }^{6 \theta}$

Neither the language of the statute nor the legislative history conclusively reveals intent on the issue of whether an EIS is required for federal actions abroad. According to the plain meaning of the statutory language, an EIS would be required. ${ }^{70}$ This is fully consistent with the congressional purpose in enacting NEPA ${ }^{71}$ and, as will be shown, could be implemented without serious international law problems. ${ }^{72}$

\section{B. The Executive Order}

The statutory ambiguity on this issue was exacerbated by a split within the executive branch on the interpretation of the EIS requirement. The Council on Environmental Quality stated its belief "that the impact statement requirement in $\S 102(2)(\mathrm{C})$ of NEPA applies to all significant effects of proposed federal actions on the quality of the human environment-in the United States, in other countries, and in areas outside the jurisdiction of any country."73 The CEQ analysis relied upon congressional intent, the legislative history, the post-enactment oversight hearings and legal analysis by courts and commentators to reach its conclusion.

In contrast, the State Department determined that " $t]$ he Act should be interpreted as applying to federal actions occurring in areas outside the jurisdiction of any other State (i.e. the high seas, Antarctica, or outer space) but should not be interpreted as applying to actions occurring within the jurisdiction of another State."74 The State Department analysis relied on the presumed extraterritoriality of an EIS procedure for federal actions abroad and the need "to avoid ill-will and conflict between nations arising out of one nation's encroachments upon another's sovereignty."7s

The controversy within the executive branch was finally laid to rest in 1979 by an Executive Order which established procedures governing the preparation of an EIS for federal actions abroad. Executive Order No. 12,114, on the Environmental Effects Abroad of Major Federal Actions, issued by President Jimmy Carter ${ }^{76}$ takes into account

ov State of Cal. v. Watt, 520 F. Supp. 1359, 1374 (C.D. Cal. 1981).

${ }^{20}$ See supra text accompanying notes 52-53.

71 See supra note 49.

72 See infra text accompanying notes 114-154.

2s CEQ Memo, supra note 49, at 61,069.

${ }^{74}$ Memorandum of C. Herter, Special Assistant to the Secretary of State for Environmental Affairs, reprinted in Administration of the National Environmental Policy Act: Hearing Before the Subcommittee on Fisheries and Wildlife Conservation of the House Committee on Merchant Marine and Fisheries, 91st Cong., 2d Sess. 551 (1970) [hereinafter cited as State Dep't Memo]. ${ }^{78}$ Id. at 554.

${ }^{78}$ Exec. Order No. 12,114, 3 C.F.R. 356 (1980), reprinted in 42 U.S.C. $§ 4321$ (Supp. IV 
some of the foreign policy considerations relevant in defining the scope of NEPA; ${ }^{77}$ it is, however, inadequate for environmental protection because it allows agencies virtually unbridled discretion in determining whether to prepare an EIS. In addition, it does not provide a right of action against a noncomplying agency, as NEPA does. The Executive Order attempts a compromise but accepts as its underlying premise the State Department perspective that EIS preparation would constitute an infringement of foreign sovereignty.

The Order's definition of environment is narrower than NEPA's. ${ }^{28}$ The scope of the environmental statements to be prepared is narrower as well. A full EIS is only required for actions which affect the "global commons" (areas outside the jurisdiction of any nation); ${ }^{79}$ it is allowed as one of three alternatives for actions affecting globally important resources, as designated by the President. ${ }^{80}$ For all other major federal actions, ${ }^{81}$ the Order requires one of two truncated assessments-bilateral ${ }^{82}$ or concise ${ }^{83}$ reviews-or, in the case of most actions $^{84}$ with effects confined to the nation in which the action takes place, no environmental assessment at all. ${ }^{\mathbf{8 5}}$

There is a list of exemptions, most of which are consistent with NEPA. ${ }^{88}$ Thereafter, however, is a list of "considerations" which allow an agency to modify the process if it needs to "decide and act

1980) [hereinafter cited as Exec. Order].

77 See infra text accompanying notes 97-154.

"Exec. Order, supra note 76, § 3-4. The definition includes "the natural and physical" environment but "excludes social, economic and other environments." That conflicts with case law to a certain extent. Once an impact on the environment is established, a domestic EIS considers a range of social, economic, and cultural factors. See supra note 14. See also Sierra Club v. Coleman, 405 F. Supp. 53 (D.D.C. 1975), vacated and remanded sub nom. Sierra Club v. Adams, 578 F.2d 389 (D.C. Cir. 1978). Such a limited definition may represent a valid foreign policy limitation in some circumstances. President Carter presumably thought that consideration of such factors would conflict too much with foreign sovereignty. In any particular case that may be true; in many, it may not be. In any case, a balancing approach seems preferable. See infra notes 155-201 and accompanying text.

72 Exec. Order, supra note 76, § 2-4(b)(i).

so Id. \& 2-4(b)(iv).

$"$ See id. \$ 2-3.

sI Id. § 2-4(ii).

as. \& 2-4(iii).

$\boldsymbol{m}$ Actions with effects limited to the nation where the action takes place require an assessment only if the action involves toxic products or radioactive substances. Id. § 2-3(c).

a For example, construction of a hydroelectric project would require no environmental asessment, despite its potential for causing floods and dislocation of population. See Comment, The "NEPA-Abroad" Controversy: Unresolved by an Executive Order, 30 BUFFaLo L. REv. 611, 653 (1981).

se See Gaines, "Environmental Effects Abroad of Major Federal Actions": An Executive Order Ordains a National Policy, 3 HARV. ENVTL. L. REV. 136, 153-55 (1979). For example, the Executive Order exempts "actions not having a significant effect on the environment," § 2-5(a)(i), and "actions taken by the President," $\& 2-5(a)(i i)$. Neither of these would require an EIS under NEPA because NEPA only applies to actions of federal agencies which have significant effects. 42 U.S.C. $\S 4332(2)(1976)$. 
promptly," other nations' sovereign responsibilities."88 Other "concerns" allowing modification include a need for "commercial confidentiality" serted "difficult[y] of obtaining information and agency [in]ability to analyze meaningfully environmental effects of a proposed action.",90 What emerges from the "considerations" is a license for agencies to interpret the Executive Order with a "begrudging attitude"91 and avoid. environmental considerations virtually at will.

The Order "is solely for the purpose of establishing internal procedures for Federal agencies ... . and nothing in this Order shall be construed to create a cause of action." group may not base its claim on the Executive Order to require review of a federal agency's proposed action. ${ }^{93}$ The ability of private parties to challenge a decision not to prepare an EIS, or to question its adequacy, has been a principal reason for NEPA's success. ${ }^{94}$ A properly drafted order, giving full effect to the mandates of NEPA, would have reduced confusion and facilitated enforcement of the Act had it provided for a private right of action. ${ }^{85}$

Thus, potential litigants still seek an interpretation of NEPA which would allow judicial review of environmental impact analysis for federal actions abroad. ${ }^{96}$ Such an interpretation must overcome the major policy argument against requiring an EIS for federal actions abroad; that is, the belief that such a requirement would constitute an unreasonable infringement on foreign sovereignty.

${ }^{87}$ Exec. Order, supra note 76, § 2-5(b)(i).

Bs Id. \& 2-5(b)(ii) (emphasis added).

80 Id. § 2-5(b)(iii)(3).

${ }^{\infty 0}$ Id. § 2-5(b)(iii)(5).

92 Comment, supra note 85, at 656 (quoting CEQ criticism of the Defense Department's regulations adopted under the Executive Order).

92 Exec. Order, supra note 76, § 3-1.

93 If an agency did not comply with the Order, a plaintiff could sue under NEPA, see supra note 21 and accompanying text, and could, of course, cite the Order for its persuasive value, since it represents the considered view of the President as to how to further the purpose of NEPA. See Exec. Order, supra note $76, \S 1-1$. If the agency has complied, it similarly may invoke the Order. But a reviewing court must still interpret the statutory (NEPA) directive to determine whether the agency has in fact complied with the Act.

or See supra text accompanying note 21 .

${ }^{95}$ The President might not have had the power to have done so, however, since the creation of a right of action is a legislative function reserved for Congress. See Touche Ross \& Co. v. Redington, 422 U.S. 560, 575-78 (1979).

- See Gaines, supra note 86, at 158. 


\section{Does Requiring an EIS for Federal Actions Abroad CONSTITUTE AN INFRINGEMENT ON ForeigN SOVEREIGNTY?}

\section{A. General Considerations}

The reluctance to require EIS's for major federal actions abroad stems from the belief that assessment of the impact of such actions in other countries would infringe upon foreign sovereignty. The State Department's position illustrates this well. ${ }^{97}$ State concluded that requiring an EIS for actions occurring in the global commons is appropriate, ${ }^{98}$ whereas those actions occurring within another sovereign's jurisdiction should be exempt from such requirement. ${ }^{98}$ The State Department recognized that Congress did not intend to limit the scope of NEPA to the territorial United States ${ }^{100}$ but was anxious "to avoid illwill and conflict between nations arising out of one nation's encroachment upon another's sovereignty."101

It is indeed important for the United States to respect the spirit of comity among nations and to avoid environmental and economic policies which smack of a "new imperialism."102 It is questionable, however, whether American programs would appear more "imperialistic" if tempered with environmental concerns. As it is, foreign development projects are imbued with American standards and priorities. The addition of environmental concerns would merely be another American factor in foreign project decisionmaking. As one commentator detailed the process:

$[\mathrm{M}]$ any projects are conceived, planned, and supervised wholly by American officials. 'Applications' for loans are often written at the AID [Agency for International Development] mission and sent to the recipient only for signature. Foreign governments should have decisionmaking authority so that they can implement their own development priorities and objectives. But, given current procedures, AID's myth serves only as an excuse for giving inadequate consideration to the environment. ${ }^{103}$

State Dep't Memo, supra note 74, at 546.

* Id. at 554 .

- Id. at 554-55.

100 Id. at 554.

101 Id.

${ }^{102}$ For a general discussion deploring the application of United States legal standards to actions in other nations, see Grundman, The New Imperialism: The Extraterritorial Application of United States Law, 14 INT'L LAW. 257 (1980).

${ }^{103}$ Comment, supra note 29 , at 347. 
Lesser-developed countries may indeed view American environmental policy as an encroachment on their sovereignty. They may feel it is unfair for the United States, which accumulated its wealth while largely ignoring environmental concerns, to limit their growth through environmental controls:

The arguments in support of their position, now familiar, focus first on the inequity of requiring the less developed countries to divert scarce resources to environmental quality in order to rectify the past environmental depredations of developed nations; and second, on the financial burden that the developed nations themselves should bear in order to achieve environmental quality. ${ }^{104}$

The experience of AID demonstrates, however, that developing countries are concerned about the environment. ${ }^{105}$ Those nations have "come increasingly to recognize the interrelated nature of environment and development"106 and to appreciate environmental analysis which provides a framework for environmentally responsible projects.

Concerns that environmental analysis will result in additional financial burden on developing countries are not insuperable. First, an EIS does not necessarily result in a more costly alternative; rather, it may save the foreign government money. ${ }^{107}$ Second, if indeed it is found that American environmental standards are increasing the costs of essential development programs, the United States may consider adding an amount to its grant to offset the economic loss caused by environmental protection.

Finally, the preparation of an EIS should be viewed as an attempt to respect foreign sovereignty by providing information to the foreign nation. ${ }^{108}$ In the domestic context, one court has stated, "[a]t the very least, NEPA is an environmental full disclosure law."109 Other countries have a need to know the potential negative consequences of United States actions within their borders. ${ }^{110}$ They may not have the technical capacity to determine those consequences themselves. ${ }^{111}$ An EIS sug-

100Tarlock, The Application of the National Environmental Policy Act of 1969 to the Darien Gap Highway Project, 7 N.Y.U. J. INT'L L. \& POL. 459, 468 (1974).

${ }_{108}$ At the request of the Office of Management and Budget, the Agency for International Development prepared an analysis of its experiences with NEPA. Some of its observations are quoted in CEQ documents reprinted in 124 CONG. REC. 11,801-06 (1978).

106 Id. at 11,802 .

107 See supra note 47.

10 CEQ documents, reprinted in 124 CONG. REC. 11,804 (1978).

109 Environmental Defense Fund Inc. v. Corps of Eng'rs, 325 F. Supp. 749, 759 (E.D. Ark. 1971).

110 CEQ documents, reprinted in 124 CONG. REC. 11,804 (1978).

11 Id. 
gests alternatives ${ }^{112}$ and allows the foreign government to make an intelligent, fully informed decision. ${ }^{113}$

Thus, the requirement that the United States prepare an EIS for federal actions abroad does not, per se, violate international concepts of sovereignty. While an EIS would evaluate conditions in a foreign country, it does so in connection with a United States action, and provides the other nation with information on alternatives which may preserve its environmental quality.

\section{B. Does Requiring an EIS for Federal Actions Abroad Constitute an Extraterritorial Application of United States Law?}

Another, more doctrinal way of examining NEPA's potential infringement on foreign sovereignty is to ask whether the requirement of an EIS for federal actions abroad is an extraterritorial application of United States law. The answer to that question depends upon whether one characterizes an EIS as a procedural tool for American decisionmaking ${ }^{114}$ which does not seek to prescribe conduct occurring in another state or as a process which requires other states to adopt United States environmental standards, including intrusive site-specific inspection. ${ }^{115}$ Each position is set out in more detail below.

\section{A Mere Procedural Requirement}

The typical extraterritorial application of United States law involves an action which may or may not have been legal by the standards of the country in which it took place declared illegal by a United States court. The court is on firmer ground if it rules against American citizens acting abroad, ${ }^{116}$ but it may also pass judgment upon foreign nationals. ${ }^{112}$ The American court may grant damages or provide injunctive relief. ${ }^{118}$

11242 U.S.C. § 4332(2)(C)(iii) (1976).

113 See Robinson, Extraterritorial Environmental Protection Obligations of Foreign Affairs Agencies: The Unfulfilled Mandate of NEPA, 7 N.Y.U. J. INT'L L. \& PoL. 257, 261 (1974).

${ }^{114}$ See Gaines, supra note 86, at 141.

116 See Robinson, supra note 113 , at 260 .

118 A nation may govern the actions of its citizens, wherever they ae located, under the nationality principle of jurisdiction. RESTATEMENT (REVISED OF FOREIGN RELATIONS LAW OF THE UNITED STATES $\S 402(2)$ (Tent. Draft No. 2, 1981) (hereinafter cited as REvISED RESTATEMENT].

${ }_{117}$ See, e.g., United States v. Imperial Chem. Indus., 105 F. Supp. 215 (S.D.N.Y. 1952). The foreign defendant must have some minimum contacts with the United States for an American court to exercise in personam jurisdiction.

${ }_{118}$ Jurisdiction to enforce is distinguished from jurisdiction to prescribe and refers to the ability of a state to compel or induce compliance with statutes, regulations or judgments. REVISED RESTATEMENT, supra note $116, \S 401(2)$. 
Such extraterritorial application of United States law has become a sore point with other countries, particularly when the action forbidden by the American court is encouraged by the foreign government. ${ }^{119}$ Some nations have responded to this "legal imperialism" by enacting retaliatory legislation which limits the effect of United States judgments. ${ }^{120}$

NEPA's foreign impact is quite different. The statute applies only to Americans (the administrators of federal agencies) and creates a process by which they can, while acting within the United States, reach an enlightened policy decision by taking into account foreign environmntal effects. A federal decisionmaker would have the legal obligation to prepare an EIS and to give its implications good faith consideration. ${ }^{121}$ The environmental analysis does not, however, determine the fate of the contemplated action. After weighing environmental factors, the decisionmaker remains free to subordinate those factors to other policy considerations. A project causing considerable environmental harm may still be approved:

The harm against which NEPA's impact statement requirement was directed was not solely or even primarily adverse consequences to the environment; such consequences may ensue despite the fullest compliance. Rather NEPA was intended to ensure that decisions about federal actions would be made only after responsible decisionmakers had fully adverted to the environmental consequences of the actions, and had decided that the public benefits flowing from the actions outweighed their environmental costs. ${ }^{122}$

NEPA does not declare any private action taking place abroad to

119 For example, in United States v. Watchmakers of Switz. Information Center, Inc., 1963 Trade Cas. (CCH) if 70,600 (S.D.N.Y. 1962), discussed in H. STEINER \& D. VAGTS, TRANSNATIONAL Legal ProblemS 1041-46 (1976), a United States court found American and Swiss defen-dants to be violating the Sherman Antitrust Act through their participation in a consortium controlling the export of Swiss watches to the United States. The Swiss government had encouraged the practice, and reacted to the judgment by requiring (as opposed to its former practice of permitting) the "illegal" conduct. This removed the activity from United States judicial scrutiny under the foreign compulsion doctrine. See RESTATEMENT (REVISED) OF FOREIGN RELATIONS LAW OF THE UNITED STATES § 419(1)(b) (Tent. Draft No. 3, 1982).

130 For example, the British Protection of Trading Interests Act of 1980 grants the Minister of Trade discretion to direct persons in the United Kingdom to disobey extraterritorial court orders of another country, if it is determined that compliance would damage British trading interests or infringe on British jurisdiction. See REVISED RESTATEMENT, supra note 116, at 91-92. See generally, Sornarajah, The Extraterritorial Enforcement of United States Antitrust Laws. Conflict and Compromise, 31 INT'L \& COMP. L.Q. 127 (1982).

122 See supra text accompanying notes 23-24.

122 Jones v. District of Columbia Redevelopment Land Agency, 499 F.2d 502, 512 (D.C. Gir. 1974), cert. denied, 423 U.S. 937 (1975). 
be illegal. EIS preparation "would not impose American environmental standards on any other country. Even if the federal activity abroad is unlawful in the United States, NEPA does not prevent its being undertaken abroad."123 Furthermore, since NEPA binds only American officials, there is no need to seek enforcement of the law in a foreign forum, as is the case when United States law applies to foreign defendants. ${ }^{124}$

NEPA is thus more closely akin to the myriad laws which direct federal decisionmakers to scrutinize other nations for certain types of behavior or which require certain conditions be met before extending aid or engaging in certain types of trade. The Foreign Assistance Act of $1961^{125}$ requires that before approving developmental assistance AID must consider the degree to which programs integrate women into the economy, ${ }^{126}$ as well as the possibility of using aid to "support democratic social and political trends in recipient countries." 127 The Nuclear Nonproliferation $\mathrm{Act}^{\mathbf{1 2 8}}$ requires the $\mathrm{NRC}$, before approving a nuclear export license, to consider the recipient nation's willingness to cooperate with American nonproliferation objectives. ${ }^{12 \theta}$ The Jackson-Vanik amendment to the Trade Act ${ }^{130}$ denies most-favored-nation status to Communist countries that restrict emigration. ${ }^{131}$

None of those statutes seeks to prescribe action in foreign jurisdictions. The United States cannot require foreign employers to hire more women or direct Communist states to ease emigration. Similarly, the United States would evoke great international wrath if it tried to use the Clean Air $\mathrm{Act}^{132}$ to prosecute a Mexican manufacturer whose smoke emissions did not meet EPA standards. ${ }^{133}$ NEPA, on the other hand, ceates no substantive environmental standards and compliance with its requirements is merely a step in the administration of an American program. "[I]t seems elementary that this country may properly impose conditions upon the granting of unilateral aid to any coun-

123 CEQ documents, reprinted in 124 CONG. REC. 11,802 (1978).

126 See discussion of the Imperial Chemical Industries litigation, H. STEINER \& D. VAGTS, supra note 119 , at $1029-40$.

12522 U.S.C. $\S \S 2151-2443$ (1976).

128 Id. at $\S 2151(\mathrm{k})$.

127 Id. at $\S 2218(\mathrm{c})$.

12822 U.S.C. $\S \S 3201-3282$ (1976); 42 U.S.C. $\S \S 2021-2159$ (Supp. III 1979).

12042 U.S.C. $\S \S 2156,2157$ (Supp. III 1979).

13019 U.S.C. § 2432 (a) (1976).

131 Id. See also Note, An Interim Analysis of the Effects of the Jackson-Vanik Amendment on Trade and Human Rights: The Romanian Example, 8 LAW \& POL'Y INT'L BUS. 193 (1976). 13242 U.S.C. \& 1857 (1976).

19s Similarly the Canadians would not be very successful if they attempted to apply Canadian law to our utility emissions, even assuming such emissions contribute to "acid rain." These kinds of problems can, however, be addressed by bilateral or multilateral treaties. 
try, and if it chooses to consider environmental implications in the definition of these conditions, no one can legitimately object to them."134

\section{An Effective Limitation of Foreign Choice}

It is somewhat misleading, however, to characterize the EIS requirement as a purely domestic activity. The most obviously intrusive element of an EIS review of United States actions abroad is the need to examine site-specific impacts. The scope of an EIS can be quite broad. ${ }^{135}$ In Sierra Club v. Coleman, ${ }^{136}$ the Federal Highway Administration (FHWA) was helping to construct a portion of the Pan-American Highway through the Darien gap in Panama and Colombia. The district court held that FHWA had failed to consider whether alternate routes might have a less deleterious effect on the native Choco and Cuna Indians who lived in the area of the proposed construction, ${ }^{137}$ and ordered anthropological and ethnographic analysis. ${ }^{138}$ Such analysis requires Americans or their proxies to undertake site-specific research, which may be seen as an extraterritorial application of United States law: an American court (or legislature) directs a course of action to take place within a foreign jurisdiction. And when the collected data are used by American decisionmakers to choose among available alternatives, the unavoidable infusion of American values may cause great resentment. ${ }^{139}$ In the Philippines reactor case, ${ }^{140}$ Judge Wilkey recognized that application of NEPA abroad lacks the prescriptive nature of other extraterritorial reaches, yet realized the limitations that an EIS might impose on a foreign nation's choices, declaring that "failure to perceive extraterritorial consequence[s] . . . would be naive."141 Thus, while a strong case can be made that the EIS requirement is not an extraterritorial application of United States $\operatorname{law}^{142}$ and that any infringement of national sovereignty is limited, ${ }^{143}$ we must recognize the potential for international disagreements as to the scope and legitimacy

134 H.R. REP. No. 316, 92d Cong., 1st Sess. 33 (1971) (NEPA Oversight hearings).

135 "Human environment," 42 U.S.C. $\S 4332(2)$ (C) (1976), has been construed to include the physical, aesthetic, historic, cultural, social and economic dimensions of environmental impacts.

EIS REPORT, supra note 15, at 49.

136 405 F. Supp. 53 (D.D.C. 1975) (injunction issued halting construction).

197 Id. at 56.

13s 421 F. Supp. 63, 68 (D.D.C. 1976) (ruling on the sufficiency of the final EIS).

139 Usually, however, not enough resentment to cause the foreign country to refuse the United States aid.

${ }^{140}$ Natural Resources Defense Council, Inc. v. Nuclear Regulatory Comm'n, 647 F.2d 1345

(D.C. Cir. 1981).

141 Id. at 1357.

142 See supra text accompanying notes $116-34$.

143 See supra text accompanying notes 97-113. 
of American legislation in this area. These more intrusive aspects of the EIS requirement must be scrutinized against traditional standards of international law.

When Congress does not explicitly outline a statute's extraterritorial consequences, the courts will assume that the jurisdictional reach of the statute comports with international law. ${ }^{144}$ The standards in international law ${ }^{148}$ governing how far a state may extend the reach of its laws have historically been expressed through fairly rigid legal doctrines, ${ }^{146}$ based, for example, on where the regulated activity took place or on the nationality of the actor. The requirement that an EIS be prepared for federal actions abroad fits easily within such established principles. $^{147}$

The conduct involved in preparing and using an EIS in federal decisionmaking may be justified as conduct occurring within the territory of the United States. Even when a site-specific examination in a foreign country is required, a substantial part of the EIS preparation and use will occur within the United States as agencies located within the United States evaluate a project. Examinations and decisions which take place "in the field" (within the foreign jurisdiction) will require the consent of the foreign state to enter the jurisdiction but will not require the United States government to direct the other state's activities, as inspections will be made by United States government employees. The EIS requirement may also be justified under an effects analysis because if the proposal is approved, it may have substantial environmental effect within the United States. ${ }^{148}$

14 See, e.g., Lauritzen v. Larsen, 345 U.S. 571, 578 (1953); Murray v. The Schooner Charming Betsy, 6 U.S. (2 Cranch) 64, 118 (1804).

145 International law is part of the domestic law of the United States. See The Paquete Habana, 175 U.S. 677 (1900).

168 They are: territorial, based on the place where the action occurred; nationality, allowing jurisdiction over one's own nationals for actions undertaken abroad; protective, referring to the national interests of the forum state; universality, by which certain heinous criminals can be tried anywhere; and passive personality, referring to the nationality of the injured party. These principles are listed in decreasing order of acceptance. See Almond, Reach of United States Regulatory Authority Over Environmental Impacts of its Activities, 44 ALB. L. REV. 739, 763 (1980).

147 These principles are set forth in the REVISED RESTATEMENT, supra note 116, as follows:

$\S 402$. Bases of Jurisdiction to Prescribe

Subject to $\S 403$, a state may, under international law, exercise jurisdiction to prescribe and apply its law with respect to

(1)(a) conduct a substantial part of which takes place within its territory;

(b) the status of persons, or interests in things, present within its territory;

(c) conduct outside its territory which has or is intended to have substantial effect within its territory;

(2) the conduct, status, interests or relations of its nationals outside its territory. . . .

218 See id. at $\S 402(1)(c)$ for the effects test in international jurisdiction. 
While requiring an EIS for federal actions abroad is acceptable under traditional principles of jurisdiction, it must also be scrutinized under a "reasonableness" test that courts have recently used to supplement such principles, which often seemed unfairly rigid. ${ }^{140}$ The test simply tempers those principles in light of the interests of the recipient country. That analysis was used in Timberlane Lumber Co. v. Bank of America, ${ }^{150}$ where the Ninth Circuit held that even though it had the proper subject-matter jurisdiction, as a matter of international comity and fairness it must balance the competing interests of the countries involved to determine whether United States extraterritorial jurisdiction should be asserted. ${ }^{151}$ This "jurisdictional rule of reason,"162 which has been adopted by the Restatement, ${ }^{153}$ will be used in the next section to

148 See infra note 153 .

180549 F.2d 597 (9th Cir. 1976); see also In re Uranium Antitrust Litigation, 617 F.2d 1248 (7th Cir. 1980); Mannington Mills, Inc. v. Congoleum Corp., 595 F.2d 1287 (3d Cir. 1979). 181549 F.2d at 613-15.

The elements to be weighed include the degree of conflict with foreign law or policy, the nationality or allegiance of the parties and the locations or principal places of business of corporations, the extent to which enforcement by either state can be expected to achieve compliance, the relative significance of effects on the United States as compared with those elsewhere, the extent to which there is explicit purpose to harm or affect American commerce, the foreseeability of such effect, and the relative importance to the violations charged of conduct within the United States as compared with conduct abroad.

Id. at 614.

183 Id. at 613.

168 \$ 403 Limitations on Jurisdiction to Prescribe:

(1) Although one of the bases for jurisdiction under $\S 402$ is present, a state may not apply law to the conduct, relations, status, or interests of persons or things having connections with another state or states when the exercise of such jurisdiction is unreasonable.

(2) Whether the exercise of jurisdiction is unreasonable is judged by evaluating all the relevant factors, including:

(a) the extent to which the activity (i) takes place within the regulating state, or (ii) has substantial, direct, and foreseeable effect upon or in the regulating state;

(b) the links, such as nationality, residence, or economic activity, between the regulating state and the persons principally responsible for the activity to be regulated, or between that state and those whom the law or regulation is designed to protect;

(c) the character of the activity to be regulated, the importance of regulation to the regulating state, the extent to which other states regulate such activities, and the degree to which the desirability of such regulation is generally accepted;

(d) the existence of justified expectations that might be protected or hurt by the regulation in question;

(e) the importance of regulation to the international political, legal or economic system;

(f) the extent to which such regulation is consistent with the traditions of the international system;

(g) the extent to which another state may have an interest in regulating the activity;

(h) the likelihood of conflict with regulation by other states. 
test the reasonableness of NEPA's EIS requirement. ${ }^{154}$

Thus far, this Comment has argued that the preparation of an EIS for federal actions abroad would make a substantial contribution toward the goal of environmental protection. Concern about potential infringements of sovereignty led to the promulgation of an Executive Order which is inconsistent with the directives of NEPA because it restricts the scope of the EIS requirement. While certain valid objections can be made to a requirement of an EIS for federal actions abroad, those objections can best be dealt with within the statutory framework of NEPA, supplemented by judicial review using a balancing standard.

\section{A Balancing APPROACH}

\section{A. The Statutory Framework}

Courts should require agencies to go beyond the Executive Order and adhere to the requirements of NEPA itself for two reasons. First, as discussed above, ${ }^{105}$ strong arguments can be made that the Order does not execute the Act. Second, the EIS requirement of NEPA is sufficiently flexible to accomodate concerns of sovereignty in the context of federal actions abroad.

Section 102(2)(C) states that "to the fullest extent possible" all agencies shall prepare environmental impact statements on major federal actions. ${ }^{158}$ This phrase has been read expansively to ensure strict compliance with the statute, ${ }^{\mathbf{1 5 7}}$ but it was also intended to allow an agency to avoid preparing an EIS if an "existing law applicable to such

(3) An exercise of jurisdiction which is not unreasonable according to the criteria indicated in Subsection (2) may nevertheless be unreasonable if it requires a person to take action that would violate a regulation of another state which is not unreasonable under those criteria. Preference between conflicting exercises of jurisdiction is determined by evaluating the respective interests of the regulating states in light of the factors in Subsection (2).

REVISED RESTATEMENT, supra note $116, \S 403(1)-(3)$.

184 The court in the Philippines reactor case also called for a conflict of laws analysis, but it did not explicitly delineate the relevant factors. Natural Resources Defense Council v. Nuclear Regulatory Comm'n., 647 F.2d 1345, 1357 (D.C. Cir. 1981) ('Some balancing, or recognition of latent conflict of laws, would seem judicious to reconcile the separate but not inconsistent national interests to regulate reactors with an eye to health, safety and the environment.").

${ }^{165}$ See supra notes 73-91 and accompanying text.

156 42 U.S.C. $\S 4332(2)$ (1976) (emphasis added).

107 We must stress as forcefully as possible that the language does not provide an escape hatch for footdragging agencies; it does not make NEPA's procedural requirements somehow "discretionary." Congress did not intend the Act to be such a paper tiger. Indeed, the requirement of environmental consideration "to the fullest extent possible" sets a high standard for agencies, a standard which must be rigorously enforced by the reviewing courts.

Calvert Cliffs Coordinating Comm. v. Atomic Energy Comm'n, 449 F.2d 1109, 1114 (D.C. Cir. 1971), cert. denied, 404 U.S. 942 (1972). 
agency's operation does not make compliance possible."158 In Flint Ridge Development Co. v. Scenic Rivers Association of Oklahoma, ${ }^{159}$ the Supreme Court construed a statute which gave the Secretary of Housing and Urban Development only thirty days to act to suspend a land development disclosure statement. Otherwise it would automatically become effective. The Court held that the statutorily mandated thirty-day limit precluded the application of NEPA's EIS requirement because it would be impossible to complete the EIS process within thirty days. ${ }^{160}$

A similar statutory conflict arguably existed in Natural Resources Defense Council, Inc. v. Nuclear Regulatory Commission, ${ }^{161}$ which involved the export of a nuclear reactor to the Philippines. Approval of a license for a nuclear power plant is a major federal action because of the great degree of federal control and responsibility involved, ${ }^{\mathbf{1 6 2}}$ so this was prima facie covered by NEPA. The majority opinion did not require EIS preparation but Judge Robinson's concurrence ${ }^{163}$ rested specifically on a statutory conflict with the Nuclear Nonproliferation Act of $1978 .{ }^{164}$ Congressional policy underlying that Act envisions the United States preventing proliferation of nuclear arms by establishing itself as a supplier of nuclear energy for peaceful purposes, thus preempting less responsible suppliers who might not control weaponsgrade materials as scrupulously. ${ }^{165}$ That policy requires quick, affirmative action which would arguably be hindered by preparation of an EIS. This statutory conflict exception can be extended to other areas of foreign action in which Congress demands swift action.

That "escape clause" could be used by courts to avoid conflicts between requiring an EIS and the limitations of international law. The extraterritorial application of United States law should be limited so as not to encroach unreasonably on another state's sovereignty, ${ }^{166}$ particularly if Congress did not expressly intend otherwise. ${ }^{167}$ Thus, while the general presumption established in NEPA would require the prepara-

1ss Section-by-section analysis of Senate changes to NEPA, reprinted in 115 CONG. REC. 40,417-19.

168 426.U.S. 776 (1976).

${ }^{100}$ Id. at 791; see also United States v. Students Challenging Regulatory Procedures (SCRAP), 412 U.S. 669 (1973) (when forced compliance with NEPA would undermine purpose of $\S 15(7)$ of the Interstate Commerce Act, courts have no jurisdiction to enjoin compliance).

${ }^{261} 647$ F.2d 1345 (D.C. Cir. 1981).

${ }_{162}$ Calvert Cliffs Coordinating Comm. v. Atomic Energy Comm'n, 449 F.2d 1109, 1110-14

(D.C. Cir. 1971), cert. denied, 404 U.S. 942 (1972).

108647 F.2d at 1385-88.

194 See supra note 128.

105647 F.2d at 1360.

108 See supra notes $147-54$ and accompanying text.

107 See supra text accompanying note 144. 
tion of an EIS for any major federal action abroad significantly affecting the environment, Section 102(2)(C) would excuse preparation of an EIS where it would unreasonably infringe another nation's sovereignty. To determine whether preparation of an EIS would infringe foreign sovereignty, a number of factors should be considered.

\section{B. Relevant Factors: Agency Determinations and Judicial Review}

The determination whether an EIS should be prepared requires consideration of the policies embodied in NEPA and the dictates of international law. The agency should first determine, using the standards it applies to domestic actions, whether an EIS is warranted ${ }^{188}$ and then decide whether the extraterritorial nature of the project allows or prohibits the preparation of an EIS. This process results in the agency's decision which is subject to judicial review upon the request of a party with standing. ${ }^{160}$ Thus, agencies will be guided in their actions by judicial precedent.

The process is not administratively infeasible. Currently, federal agencies contemplating major action conduct a preliminary environmental assessment as part of the threshold decision. ${ }^{170}$ At that point, the agency can consider the elements in the balancing equation, along with the usual domestic factors, ${ }^{171}$ as they have been enunciated by the judiciary. As with a decision on whether to prepare an EIS for domestic projects the agency will have to develop an adequate evidentiary record and faithfully consider existing precedent. ${ }^{172}$ NEPA has, however, sufficient procedural flexibility to avoid public scrutiny of secret information whose disclosure might jeopardize national security. ${ }^{173}$

Judicial review of such agency decisions has developed an implied cause of action under NEPA. Congress did not specify how NEPA was to be enforced, and the Act does not even mention judicial review. ${ }^{174}$ It was the courts that determined judicial review to be "crucial to NEPA

\footnotetext{
1es See supra text accompanying notes $13-17$.

168 A plaintiff has standing if he was injured in fact and was "arguably within the zone of interests to be protected or regulated by the statute." Association of Data Processing Serv. Orgs. v. Camp, 397 U.S. 150, 153 (1970); see also United States v. SCRAP, 412 U.S. 669 (1973); Sierra Club v. Morton, 405 U.S. 727 (1972); infra note 177.

170 See F. ANDERSON, supra note 14 , at 24.

171 See supra notes $13-17$ and accompanying text.

${ }^{172}$ See Citizens to Preserve Overton Park, Inc. v. Volpe, 401 U.S. 402 (1971); Scenic Hudson Preservation Conf. v. FPC, 354 F.2d 608 (2d Cir. 1965).

${ }_{178}$ "To the extent national security or essential foreign policy considerations make controlled circulation of environmental statements necessary, NEPA provides sufficient procedural flexibility to accomplish this." CEQ Memo, supra note 49 , at 61,069 .

174 F. ANDERSON, supra note 14, at 16.
} 
implementation."175 As one commentator has noted, the active role taken by the courts in "reviewing agency compliance with NEPA [is] in large part because private citizens interested in NEPA's enforcement have been granted standing to sue."176 In fact, the courts have been quite lenient in finding adequate grounds for standing. ${ }^{\mathbf{1 7 7}}$

The courts have closely scrutinized agency decisions on whether to prepare an EIS for domestic projects ${ }^{\mathbf{1 7 8}}$ so it is likely that they would be equally vigorous in reviewing agency determinations regarding extraterritorial restrictions on such preparation. The circuits are split on what should be the proper standard of review. The most widely accepted standard seems to be that a reviewing court will defer to the agency on such a decision unless the decision was arbitrary and capricious. ${ }^{178}$ Courts are also willing to overturn agency decisions if the re-

178 Citizens for Clean Air v. Corps of Engineers, 349 F. Supp. 696, 703 (S.D.N.Y. 1972); see Environmental Defense Fund v. Hardin, 325 F. Supp. 1401 (D.D.C. 1971); Students Challenging Regulatory Procedures (SCRAP) v. United States, 346 F. Supp. 189 (D.D.C. 1972), rev'd on other grounds, 412 U.S. 669 (1973); see also F. ANDERSON, supra note 14, at 16-17.

${ }^{176} \mathrm{~F}$. ANDERSON, supra note 14, at 26. The process has been similar to, although not as explosive as, the creation of a private right of action under SEC Rule 10b-5. See Herman \& MacLean v. Huddleston, 103 S. Ct. 683 (1983).

${ }^{177}$ See id. at 27-39. Although the major prerequisite to standing is injury in fact, see supra note 169 , plaintiffs alleging a "variety of aesthetic, conservational, and recreational interests" have successfully brought suit. Id. at 27 . Although a mere interest in a problem is insufficient to gain standing, Sierra Club v. Morton, 305 U.S. 345 (1972), several courts have granted standing to plaintiff organizations which could allege injury to only a few of their members. See e.g., Ward v. Ackroyd, 351 F. Supp. 1002 (D. Md. 1972); Sierra Club v. Mason, 351 F. Supp. 419 (D. Conn. 1972). At least one commentator has argued that NEPA, because it created a new right of the public to be informed of environmental effects of federal projects, in effect established a new set of injurable interests. F. ANDERSON, supra note 14, at 36 . Beyond alleging injury, the plaintiff must also show that the injury is "arguably within the zone of interests to be protected by the statute." Association of Data Processing Serv. Orgs. v. Camp, 397 U.S. 150, 153 (1970). In most cases, however, any injury that would result from the environmental impact of a project has been considered arguably within the protected zone of NEPA. See e.g., Kalur v. Resor, 335 F. Supp. 1 (D.D.C. 1971); F. ANDERSON, supra, at 30.

178 See F. ANDERSON, supra note 14, at 23.

179 See id. at 96-105. The arbitrary and capricious test is based on the Administrative Procedure Act, 5 U.S.C. $\$ 706$ (1976), which the Second Circuit found persuasive in Hanly v. Kleindienst, 471 F.2d 823 (2d Cir.), cert. denied, 412 U.S. 108 (1973). In that case the court remarked, "We see no reason for application of a different approach here since the APA standard permits effective judicial scrutiny of agency action and concomitantly permits the agencies to have some leeway in applying the law to factual contexts in which they possess expertise." Id. at 829-30. For other decisions in which the standard was applied, see, e.g., Hiram Clarke Civic Club v. Lynn, 476 F.2d 421 (5th Cir. 1973); Steele Creek Community Ass'n v. Department of Transp., 435 F. Supp. 196 (W.D.N.C. 1977), affd mem., 570 F.2d 346 (4th Cir. 1978); Mid-Shiawassee County Concerned Citizens v. Train, 408 F. Supp. 650 (E.D. Mich. 1976); Groton v. Laird, 353 F. Supp. 344 (D. Conn. 1972).

Other courts, following the Fifth Circuit's lead in Save Our Ten Acres v. Kreger, 472 F.2d 463 (5th Cir. 1973), have taken a more active judicial role by applying a test of reasonableness, relying on the Supreme Court's decision in Citizens to Preserve Overton Park v. Volpe, 401 U.S. 402 (1971). The Fifth Gircuit noted in Kreger that "Overton Park teaches that a more penetrating inquiry is appropriate for court-testing the entry-way determination of whether all relevant factors should ever be considered by the agency." 472 F.2d at 466 . For other applications of the reasonableness test, or "hard look" test, S. BREYER \& R. STEWART, ADMINISTRATIVE LAW AND REGULA- 
cord developed regarding how the decision was made is inadequate, ${ }^{180}$ although they cannot require the agencies to engage in more extensive procedures than Congress required. ${ }^{181}$ And although the courts may not substitute their own view of the facts for those of an agency, ${ }^{182}$ an administrative interpretation of NEPA and international law can be divorced from the agency's findings of fact to allow the courts to play a vigorous role in reviewing an agency's interpretation of the EIS requirement. ${ }^{183}$ Thus, it is likely that a court would perform its own balancing analysis in determining whether the agency decision was correct. $^{184}$

Although the courts have historically been reluctant to review agency decisions in the field of foreign affairs, they have not been deterred from adjudicating arguably "political questions" if the inquiry involves interpretation of a congressional directive. ${ }^{185}$ The balancing approach advocated here is designed to interpret the language of a federal statute. Additionally, the political question doctrine is a judicial means of avoiding decisions on matters in which an agency has particular expertise and which are not within the scope of judicial competence. ${ }^{188}$ In the case of NEPA there is no implementing agency (the CEQ has only an advisory role), and the judiciary has already become expert at interpreting the statutory directive underlying EIS preparation. The somewhat political nature of the extraterritorial application issue should not hinder judicial review. Thus, although the agency

TORY POLICY 291-93 (1979), see, Get Oil Out, Inc. v. Andrus, 477 F. Supp. 40 (C.D. Cal. 1979); Pokorny v. Costle, 464 F. Supp. 1273 (D. Neb. 1979); and Simmons v. Grant, 370 F. Supp. 5 (S.D. Tex. 1974).

100 See F. ANDERSON, supra note 14, at 23-26; see also supra note 172.

101 See Vermont Yankee Nuclear Power Corp. v. Natural Resources Defense Council, 435 U.S. 519 (1978). Chances are courts may still require agencies to take a "hard look" at all the available evidence, and to use such procedures as necessary, since that is arguably the intent of Congress. For a lively debate on the issue, see Stewart, Vermont Yankee and the Evolution of Administrative Procedure, 91 HARV. L. REV. 1805 (1978); Byse, Vermont Yankee and the Evolution of Administrative Procedure: A Somewhat Different View, 91 HARV. L. REV. 1823 (1978) and Breyer, Vermont Yankee and the Courts' Role in the Nuclear Power Controversy, 91 Harv. L. REV. 1833 (1978).

${ }^{182}$ See F. ANDERSON, supra note 14, at 96; see also Kleppe v. Sierra Club, 427 U.S. 390 (1976) (court should not substitute its own judgment for that of the agency with regard to assessment of environmental effects of a project; court's role is to ensure that agency has taken a "hard look" at such effects).

18s Sce F. ANDERSON, supra note 14, at 96.

184 While it may be argued that an agency, such as AID, that frequently must make such decisions concerning EIS's for foreign projects will develop expertise that courts should defer to, the fact remains that such decisions involve the kinds of issues (statutory interpretation, the law of foreign relations, comity) that courts are expert in.

185 See Vermilya-Brown v. Connell, 335 U.S. 377 (1948) (court ruled against State Department because the inquiry required interpretation of what Congress meant by a United States "possession").

18s See Coleman v. Miller, 307 U.S. 433 (1939). 
should make an initial determination as to preparing an EIS, using the balancing approach, the reviewing court should make its own independent determination, using the same balancing approach.

Such balancing requires explicit consideration of at least five factors:

1) Conflict with foreign law or policy. ${ }^{187}$ This factor along with the next one, the potential for direct environmental harm to the United States, should be given the most weight. Preliminarily, the agency should determine whether the foreign government objects to preparation of an EIS. ${ }^{188}$ If there is no objection, then the EIS can be prepared with the cooperation of that government and there is no sovereignty issue. If the recipient nation does object to an EIS, requiring one is not per se a violation of international law. It then becomes necessary to measure the degree of conflict with foreign law or policy that would come from applying NEPA. For example, the foreign government will be most vociferous in objecting to NEPA review if it has its own substantive environmental laws or NEPA-like procedures, ${ }^{189}$ especially if they have already been applied administratively or judicially. For example, in In re Babcock \& Wilcox, ${ }^{190}$ a German environmental group petitioned the Nuclear Regulatory Commission (NRG) for standing to challenge the export of a nuclear reactor to Germany. Germany had already conducted a hearing at which the petitioners were allowed to raise environmental concerns in their challenge to construction of the reactor. German law had already affirmatively addressed environmental concerns, so if the NRG had granted standing the interference with foreign sovereignty would have been great. Consequently, the petition was refused. ${ }^{191}$

2) Potential for direct environmental harm to the United States. This factor requires analysis of the probability of direct harm to the United States as well as the magnitude of such harm. The greater the

187 This was the first factor considered in Timberlane Lumber Co. v. Bank of America, 549 F.2d 597 (9th Cir. 1976), and is reflected in the REVISED RESTATEMENT, supra note 116, $\S 403(\mathrm{~g}) \&(\mathrm{~h})$.

${ }_{188}$ This would be determined through a demarche by the State Department to the other government.

189 Some of the countries that have been impressed with the United States EIS procedure and have adopted environmental assessments of their own are: Canada, Columbia, Japan, New Zealand, the Soviet Union, Australia, the German Democratic Republic, the Federal Republic of Germany, Sweden, and France. Lutz, Directions of Environmental Law in the International System: An Assessment of Tasks and Challenges for Lawyers, in ENVIRONMENTAL POLLUTION AND INDIVIDUAL RIGHTS: AN INTERNATIONAL SYMPOSIUM 191, 192 (International Bar Ass'n 1978).

1005 N.R.C. 1332 (1977).

191 Id. Also, the "full disclosure" justification for applying NEPA abroad, supra text accompanying notes 108-13, does not apply when the foreign government has its own, adequate review process. 
potential injury, the more important it is that United States law apply and an EIS be prepared to protect the primary beneficiaries of NEPA, the American people.

This factor is an extension of the effects doctrine for determining jurisdiction in international law, whereby a country claims jurisdiction based on the significant effect that the activity has on that country. The doctrine is presently applied to economic effects, such as antitrust violations abroad that restrain American trade. ${ }^{102}$ The original and more widely accepted prong of the effects doctrine, however, involves direct, physical effects, such as firing a bullet from one state into another. ${ }^{193}$ Pollution moving from one state to another falls under the direct physical effects prong of the doctrine and thus provides a reasonable basis for asserting extraterritorial jurisdiction.

3) Degree of United States control over the project. Many projects are conceived and planned by United States policymakers, with little foreign participation. ${ }^{194}$ Where American participation and responsibility are large the sovereign interests of the recipient nation in preventing an EIS are smaller. On the other hand, if the project is largely the work of a foreign government, with the United States merely providing some of the funding, foreign sovereign interests are great:

To the extent that funds are transferred with no strings attached and the recipient determines the uses to be made of them, any environmental controls mandated by the U.S. would be impractical and imperialistic. But where the important planning decisions are made by U.S. officials, our government ought to be compelled to conduct a study of environmental consequences as rigorous as that required for domestic projects. ${ }^{195}$

An analogous standard is reflected in domestic NEPA jurisprudence which exempts state projects funded through revenue sharing programs from the EIS requirements. ${ }^{198}$

4) Extent of environmental assessment activity which takes place within the United States, as opposed to within the foreign jurisdiction. A project specially designed for the recipient country, such as a flood control dam, will require more site-specific research and decisions than, for example, a nuclear reactor, ${ }^{107}$ which has a more generic design, the

102 See supra note 148.

103 REVISED RESTATEMENT, supra note $116, \S 403$ reporters' note 3.

106 See supra text accompanying note 103.

195 Comment, supra note 29, at 337.

126 See, e.g., Carolina Action v. Simon, 7 Env. Rep. Cas. (BNA) 1807 (M.D.N.C. 1975).

197 This is a relative distinction. A nuclear reactor requires a great deal of on-site examina- 
effects of which may have been the subject of previous impact statements. ${ }^{188}$ Greater site-specific activity, with the specter of American technicians descending upon the foreign jurisdiction to analyze the environment, implies greater intrusion on the foreign sovereign, and weighs against an EIS.

5) Other United States interests. The United States is a country which, perhaps to a greater extent than many other nations, has defined its interests on a global level. Our ability to achieve our foreign policy goals depends in part upon our reputation as a responsible partner in projects with other nations. That more subtle American interest may weigh in favor of applying NEPA extraterritorially. Additionally, environmentally irresponsible actions in far corners of the globe may have indirect, "secondary boomerang" effects upon the United States itself. ${ }^{198}$

That last factor is less important than the others because it involves more attenuated effects on the United States. It should not be ignored by a reviewing court, however, because the United States has a legitimate interest in protecting current and future generations of Americans from the adverse effects of worldwide environmental deterioration.

\section{G. Using the Balancing Approach to Decide Cases}

The balancing-of-interests approach does not afford the same unlimited and unreviewable discretion to administrative agencies as the Executive Order. ${ }^{200}$ It requires an EIS for federal actions abroad unless preparation of an EIS conflicts with another statutory command or with international law and comity limitations. Conflict with international law is judged by balancing the listed factors. A determination not to prepare an EIS is subject to judicial review to ensure that the agency considered the relevant factors, and that its decision was neither arbitrary nor capricious. ${ }^{201}$

Using this test, it is possible to envision five categories of federal action and determine the applicability of the EIS requirement.

1) Federal action within the United States with potential effects in

tion as well. In re Babcock \& Wilcox, 5 N.R.G. 1332, 1345 n.10 (1977).

108 In Sierra Club v. Atomic Energy Comm'n, 4 ENVTL. L. REP. (ENVTL. L. INST.) 20,685

(D.D.C. 1974), the AEC agreed to prepare a generic impact statement on United States nuclear power export activities. For the result, see Energy Research and Development Administration (ERDA), Final Environmental Statement on U.S. Nuclear Power Activities 1542 (Apr. 1976).

109 See supra text accompanying notes 40-41.

200 See supra text accompanying notes 86-91.

201 See supra notes $178-83$ and accompanying text. 
other countries. ${ }^{202}$ This category would virtually always require preparation of an EIS as it involves the least infringement upon foreign sovereignty. Any examination of the project site is within United States jurisdiction, and if it is necessary to enter a foreign jurisdiction to assess impacts, the foreign government is unlikely to object because the United States is acting to protect the foreign environment without imposing any attendant costs. ${ }^{203}$ In Wilderness Society v. Morton, ${ }^{204}$ Canadian environmental groups were granted standing to intervene in a challenge to the sufficiency of an EIS prepared by the Secretary of the Interior for the trans-Alaska pipeline. One of the proposed routes for the oil included a pipeline through Canadian territory, and the other involved shipping the oil through the Juan de Fuca Straits, in which any oil spill could threaten Canadian fishing, logging and shoreline-recreation industries. ${ }^{20 s}$ The court held that the Canadian environmentalists interests were sufficiently antagonistic to the United States environmental plaintiffs' interests as to merit intervention. ${ }^{208}$ The case implies a nondiscretionary rule: when action is undertaken within the United States, any alternatives that would have foreign impacts must be covered by an EIS. ${ }^{207}$ If the foreign government refuses to allow access to examine the possible harm, the EIS will be less complete but should still be prepared with available information. Such a view allows the United States to protect the environment and follow its duty in international law not to use its territory so as to pollute that of another. ${ }^{208}$

202 This category does not cover federal actions centered in a foreign country, upon which this Comment has focused, but it is important regarding the more general issue of global environmental responsibility. Also, the case discussed shows a judicial willingness to extend NEPA's benefits to foreigners.

${ }^{203}$ It is possible that the foreign government might object on the basis that the proposed project might have beneficial "spillover" effects (e.g., jobs created in Mexico as a result of a project in Texas close to the border), which might be jeopardized by the EIS. Account can be taken of such concerns.

206463 F.2d 1261 (D.C. Cir. 1972).

208 Id. at 1262 .

200 Id. at 1262-63.

207 The State Department agrees. State Dep't Memo, supra note 74, at 552.

Impact statements for United States action with effects abroad have been successfully prepared. Examples include the Colorado River International Salinity Control Project, affecting Mexico, and an AEC EIS on the nuclear explosion in Amchitka, Alaska, which was provided to the Japanese and Canadian governments. 5 CEQ ANN. REP. 400 (1974).

sos The 1972 United Nations Conference on the Human Environment in Stockholm expressly adopted this rule of customary international law in its final documents:

Principle 21

States have, in accordance with the Charter of the United Nations and the principle [sic] of international law, the sovereign right to exploit their own resources pursuant to their own environmental policies, and the responsibility to ensure that activities within their jurisdiction or control do not cause damage to the environment of other States or of areas beyond the limits of national jurisdiction.

Principle 22

States shall co-operate to develop further the international law regarding liability 
2) Federal actions taking place in, or affecting the "global commons." There is general agreement that an EIS is required here. ${ }^{209}$ No infringement of foreign sovereignty takes place and congressional concern with the global environment ${ }^{210}$ is respected.

3) Federal actions within other countries with substantial effects on the United States. Actions within this category usually should require the preparation of an EIS, given the potential impact on the United States. For example, Sierra Club v. Adams ${ }^{211}$ involved the construction of the Darien Gap portion of the Pan-American Highway in Panama. The United States government provided two-thirds of the funding for the segment. ${ }^{212}$ Its construction presented the possibility of the spread of aftosa (hoof-and-mouth disease), a dreaded livestock killer, to the United States. ${ }^{213}$ The court held that the Federal Highway Administration's EIS adequately addressed the problem, without explicitly holding that NEPA applied at all. ${ }^{214}$

An explicit ruling based on NEPA would clarify this category, and would not be controversial as most agencies agree that an EIS is required. ${ }^{215}$ The United States obviously has strong interests in preventing the spread of aftosa to its cattle. Those interests may be overridden only if the foreign government has its own strongly protective environmental laws, preferably involving NEPA-like assessments, which make information available to federal agencies and protect the United States. In addition, as noted above, the other nation's assessment should be given deference only if that country objects to an EIS. Otherwise, an EIS should be required.

4) Federal action within another country with effects on third countries. This is the first category requiring case-by-case balancing.

and compensation for the victims of pollution and other environmental damage caused by activities within the jurisdiction or control of such States to areas beyond their jurisdiction.

Declaration of the United Nations Conference on the Human Environment, 11 I.L.M. 1416, 1420 (1972); see also Trail Smelter Arbitration (U.S. v. Can.), 3 R. Int'l Arb. Awards 1905 (1976) (arbitration over air pollution damage); Corfu Channel Case, 1949 I.C.J. 4, 10 ENVTL. L. REP. (ENVTL. L. INST.) at 50,016 n.153 (Albania held responsible for damage to a British ship).

There is a movement toward an international law and legal institutions to police environmental offenses. See generally Lutz, supra note 189; ORGANIZATION FOR ECONOMIC COOPERATION AND DEVELOPMENT, COMPENSATION FOR POLLUTION DAMAGE (1981).

${ }_{208}$ See State Dep't Memo, supra note 74; CEQ Memo, supra note 49; Exec. Order, supra note 76; Nuclear Regulatory Commmission position in In re Babcock \& Wilcox, 5 N.R.C. at 1339.

210 See supra text accompanying notes 64-67.

311578 F.2d 389 (D.C. Cir. 1978).

212 Id. at 390.

218 Id. at $390-94$.

s14 Id. at 391-92 n.14.

11 See supra note 209. 
The United States has a strong interest in protecting itself from liability, whether legal or political. That interest will be especially strong if the federal action is a project which includes the potential for a major disaster, such as a dam whose rupture might flood a neighboring country. A high degree of American control over the project is again an important factor favoring an EIS. Here, too, the strongest factor aginst an EIS would be adequate environmental protection laws in the recipient nation, coupled with a relatively small probability of harm to a neighboring country. The initial presumption, however, should favor an EIS.

5) Federal action within another country with effects confined to that country. This is the most controversial area, and it has been the subject of an explicit judicial ruling on NEPA's extraterritorial reach. In Natural Resources Defense Council v. Nuclear Regulatory Commis$\operatorname{sion}^{216}$ (the Philippines reactor case), the court held that an EIS was not required for the issuance of a nuclear export license, when the effect of the export would be confined solely to the recipient country. ${ }^{\mathbf{2 1 7}}$ The majority mentioned conflicts of law, ${ }^{\mathbf{2 1 8}}$ but did not proceed to balance interests. The decision seemed to rest on a belief that this was an area more appropriate for international cooperation than unilateral EIS review. ${ }^{219}$ Judge Robinson's concurring opinion was more convincing, however, as it relied on the conflict between EIS review and the time requirements of the Nuclear Nonproliferation Act (NNPA). ${ }^{220}$

The holding is probably sound from a legal standpoint, although it is at least arguable that Congress did not intend the NNPA to override an EIS requirement. ${ }^{221}$ Nevertheless, the decision, which gave considerable weight to the court's view of public policy, may from that standpoint be unwise. The Philippine Islands are located in one of two of the world's earthquake belts and are in a volcano belt as well. ${ }^{222}$ The site of the proposed reactor was about five miles from Mount Natib, ${ }^{223}$ a volcano which would probably be considered "active" under NRC criteria. ${ }^{224}$ The site was also near two United States bases with thousands of American citizens. The Philippines have no stable salt formations and thus are in no position to dispose of radioactive

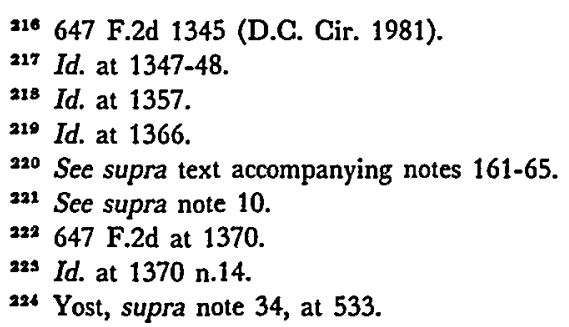


wastes. ${ }^{225}$ An EIS would have made that clearer to the agency that granted the license. Additionally, an EIS would have revealed that other energy sources, such as hydropower or geothermal energy, would have been considerably cheaper. ${ }^{22 B}$

The court in the Philippines reactor case specifically limited its holding to nuclear exports whose effects are confined to the recipient country. It left open the question of NEPA's extraterritorial reach generally, ${ }^{227}$ so a balancing approach remains appropriate. Under NEPA, a federal agency acting abroad should usually expect to prepare an EIS for such a project. If the recipient government objects, the agency should weigh the competing interests. Any effect on globally important resources would weigh in favor of an EIS. Potential for truly horrible effects on the local population and a high degree of United States control over the project would imply a moral duty in favor of an EIS. It should be kept in mind that the preparation of an EIS in no way means the project must be cancelled. It simply ensures rational decisionmaking and the consideration of available alternatives. ${ }^{228}$

On the other hand, since this category involves the greatest possible infringement on foreign sovereignty, an EIS should not be prepared if it mainly involves analyzing competing social decisions, such as whether to relocate the Indian tribes in the Panama highway case. ${ }^{229}$

\section{CONCLUSION}

This Comment has reviewed the issue of whether an EIS should be required for federal actions abroad. The extraterritorial reach of the National Environmental Policy Act was not explicitly considered by Congress, so the Comment considered policy reasons for and against EIS's for foreign projects, and concluded that although NEPA applies to agency action concerning foreign projects and EIS's are generally required, they are not required in every case. Exceptions based on a balancing-of-interests approach that limits extravagant reaches of national jurisdiction would suffice to meet both the language of NEPA and international-law and foreign-policy objections. ${ }^{230}$

There are those who believe that applying NEPA to foreign projects will harm United States interests by imposing requirements

\footnotetext{
218 Id.

228 Id. at 533-34.

227647 F.2d at 1366.

223 See supra note 22 and accompanying text.

239 See supra note 136.
}

230 Needless to say, the main problem with a balancing approach as a guide to deciding cases is that it provides little concrete aid to a judge faced with a hard case. On the other hand, the problem does not easily lend itself to mechanical tests. See supra notes 2-9 and accompanying text. 
that foreign governments will avoid by turning to other countries for aid. Those other countries may be hostile to the United States, and in any case might not share our concern for the environment. ${ }^{231}$ That is a myopic view. Proper environmental management, inspired by NEPA but accepted by other nations as well, ${ }^{232}$ will not only enhance the United States global reputation, but may also enhance our national security as the probability of global resource conflicts is reduced. Additionally, future generations will have a better chance of inheriting a habitable earth. In an era of global interdependence NEPA's prescription of minimally infringing environmental analysis should be applied to most federal actions abroad, with proper but not extravagant respect paid to foreign sovereignty.

231 For the view that applying NEPA to United States projects abroad amounts to a form of unilateral disarmament, see Almond, supra note 146.

223 See supra note 198. 


\section{.}

